\title{
Monosomic and molecular mapping of adult plant leaf rust resistance genes in the Brazilian wheat cultivar Toropi
}

\author{
P.R. Da-Silva ${ }^{1}$, S.P. Brammer ${ }^{2}$, D. Guerra ${ }^{3}$, S.C.K. Milach ${ }^{3,4}$, \\ A.L. Barcellos ${ }^{2,5}$ and M.I. Baggio ${ }^{2}$ \\ ${ }^{1}$ Laboratório de Genética e Biologia Molecular Vegetal, \\ Departamento de Ciências Biológicas, Universidade Estadual do Centro-Oeste, \\ Guarapuava, PR, Brasil \\ ${ }^{2}$ Empresa Brasileira de Pesquisa Agropecuária, \\ Centro Nacional de Pesquisa de Trigo, EMBRAPA Trigo, Passo Fundo, \\ RS, Brasil \\ ${ }^{3}$ Universidade Federal do Rio Grande do Sul, Porto Alegre, RS, Brasil \\ ${ }^{4}$ Pioneer Sementes Ltda., Centro de Pesquisa de Passo Fundo, Passo Fundo, \\ RS, Brasil \\ ${ }^{5}$ OR Melhoramento de Sementes Ltda., Passo Fundo, RS, Brasil \\ Corresponding authors: P.R. Da-Silva / S.P. Brammer \\ E-mail: prsilva@unicentro.br/sandra@cnpt.embrapa.br
}

Genet. Mol. Res. 11 (3): 2823-2834 (2012)

Received May 28, 2012

Accepted July 16, 2012

Published August 24, 2012

DOI http://dx.doi.org/10.4238/2012.August.24.7

\begin{abstract}
Leaf rust is one of the most destructive diseases affecting wheat worldwide. The most effective way to control it is to use resistant cultivars. Resistance based on slow-rusting adult plant resistance (APR) genes has proven to be the best method for developing cultivars with durable resistance. A source of slow-rusting APR for leaf rust is the Brazilian wheat cultivar Toropi. The Toropi/IAC $13 \mathrm{~F}_{2}$ and $\mathrm{F}_{7}$ recombinant inbred lines (RILs) were developed in previous studies. Phenotypic analysis of the $\mathrm{F}_{2}$ and $\mathrm{F}_{7}$ RILs showed that 2 recessive genes that were temporarily named trp- 1 and trp-2 conferred APR in Toropi. In the present study, we used monosomic families and amplified
\end{abstract}


fragment length polymorphism (AFLP), sequence-tagged site, and simple sequence repeat (SSR) markers to map trp-1 and trp-2 on wheat chromosomes. Analysis of the $\mathrm{F}_{2}$ monosomic RIL showed that trp1 and trp-2 were located on chromosomes $1 \mathrm{~A}$ and $4 \mathrm{D}$, respectively. AFLP analysis of the $\mathrm{F}_{7}$ RIL identified 2 independent AFLP markers, $\mathrm{XPacgMcac3}$ and XPacgMcac6, which were associated with Toropi APR. These markers explained $71.5 \%$ of the variation in the phenotypic data in a multiple linear regression model. The AFLP markers XPacg/ Mcac3 and XPacg/Mcac6 were anchored by SSR markers previously mapped on the short arms of chromosomes 1A (1AS) and 4D (4DS), respectively. The trp-2 gene is the first leaf rust resistance gene mapped on wheat chromosome 4DS. The mapping of trp-1 and trp-2 provides novel and valuable information that could be used in future studies involving the fine mapping of these genes, as well as in the identification of molecular markers that are closely related to these genes for markerassisted selection of this important trait in wheat.

Key words: Triticum aestivum L.; Slow-rusting; Durable resistance; Non-race-specific resistance; Molecular markers

\section{INTRODUCTION}

Puccinia triticina Erikss (Anikster et al., 1997), a causal agent of leaf rust, is the most widely distributed and frequently occurring wheat pathogen in the world. Leaf rust is common in South America, and under favorable environmental conditions, it can cause significant damage to most wheat cultivars grown in this region (Bjarko et al., 1988; Barcellos et al., 2000; Huerta-Espino et al., 2011). Host plant resistance genes have been used to control this disease. Many of these resistance genes are effective at both the seedling and adult plant growth stages and exhibit hypersensitive reactions that facilitate the emergence of virulent pathogen mutants, which can rapidly overcome the resistance (Lagudah, 2011). A few genes confer resistance during the adult plant growth stage and have the capacity to express slow-rusting resistance (Singh et al., 2011). In most cases, if the gene is recessive or partially recessive, it exhibits continuous variation in segregating populations and is under oligogenic control (Bjarko et al., 1988). To date, 4 slow-rusting adult plant resistance (APR) loci (resistant to leaf rust) have been identified, given gene designations, and mapped to specific genomic locations. These 4 loci are $L r 34$, Lr46, Lr67, and Lr68 (William et al., 2006; Krattinger et al., 2009; Herrera-Foessel et al., 2011, 2012). Among these 4 slow-rusting APR loci, the most frequently used is the Lr34 complex from the South American cultivar "Frontana" (Roelfs, 1988). Genetic analysis of Frontana has indicated that its APR is based on the additive effects of $L r 34$ as well as 2 or 3 additional rust resistance genes (Singh and Rajaram, 1992). A refined analysis of Lr34 loci has revealed that Lr34 protein resembles adenosine triphosphate-binding cassette transporters of the pleiotropic drug resistance subfamily (Krattinger et al., 2009). In Mexico, plant varieties containing the Lr34 complex have exhibited a stable response in the environments tested so far, with final leaf rust ratings lower than $5 \%$ even under heavy rust pressure (Singh et al., 2005). Another important source for leaf rust APR different from those for $\operatorname{Lr} 34, \operatorname{Lr} 46, \operatorname{Lr} 67$, and $\operatorname{Lr} 68$ has 
been identified in the Toropi cultivar from southern Brazil. This cultivar has demonstrated long-term resistance of more than 30 years under high inoculum pressure of wheat leaf rust in southern Brazil. Barcellos et al. (2000) have shown that 2 recessive genes confer APR from Toropi. However, the chromosomal location of these genes remains unknown.

Monosomic wheat series $(2 \mathrm{n}=6 \mathrm{x}=41)$ have been used to map a large number of genes on chromosomes. This type of monosomic analysis is most commonly used when trait inheritance patterns have been determined. Important wheat leaf rust resistance genes have been located on specific wheat chromosomes since Sears introduced this mapping method approximately 70 years ago (Sears, 1939). These genes include $\operatorname{Lr} 18$ on chromosome 1A (Bai et al., 1998); Lr45 on chromosome 2A (McIntosh et al., 1995); genes resistant to P. triticina, P. graminis, P. striiformis, and Erysiphe graminis on chromosome 2A (Bariana and McIntosh, 1993); 2 inserted chromosomal segments carrying resistance genes to leaf rust and greenbug initially located on chromosome 7S of Triticum speltoides and then transferred to chromosome 7A of hexaploid wheat (Dubcovsky et al., 1998), and Lr39 introgressed from Aegilops tauschii on chromosome 2D (Raupp et al., 2001).

SSR (simple sequence repeats) markers have been used in many studies for gene tagging and mapping; however, published wheat SSR maps are not saturated. This complicates the identification of SSR markers associated with wheat genes, especially on chromosome $4 \mathrm{D}$, which is poorly saturated with SSR markers. Therefore, the use of a technique with whole coverage of the genome is recommended. According to Vos et al. (1995), AFLP (amplified fragment length polymorphism) fingerprints can be used to generate linkage maps or identify molecular markers linked to phenotypic traits and/or genetic loci. These fingerprints can also be used to identify specific DNA samples or access the relatedness of various samples (Lin and Kou, 1995). The AFLP technique combines the strengths of different marker systems and provides opportunities for mapping plants with large genomes and low polymorphism rates, such as wheat. Recently, several studies have described the association of AFLP markers with important resistance genes, such as greenbug and Fusarium head blight resistance in wheat (Weng and Lazar, 2002; Guo et al., 2003), powdery mildew resistance in tomato (De Giovanni et al., 2004), and SCMV and RppQ resistance in corn (Dussle et al., 2003; Chen et al., 2004).

In this study, we mapped the adult plant leaf rust resistance genes trp- 1 and trp-2 on chromosomes 1A and 4D from the Brazilian wheat cultivar Toropi by using monosomic stocks and AFLP, SSR, and sequence-tagged site (STS) molecular markers.

\section{MATERIAL AND METHODS}

\section{Monosomic development and analysis}

Crosses of Toropi with the Cappelle-Desprez monosomic series, and cytological selections from the $\mathrm{F}_{1}$ population were made at the John Innes Centre, Norwich, England. The monosomic progeny of chromosome $1 \mathrm{~B}$ was not available for testing. The monosomic $\mathrm{F}_{2}$ population was planted at the Brazilian Wheat Research Center (Embrapa Trigo, Passo Fundo, Brazil) and was tested together with the parents in the greenhouse for APR to leaf rust. The completely expanded flag leaf of the main tiller was inoculated $(1.5 \mathrm{mg}$ spores $/ \mathrm{mL}$ mineral oil) using an atomizer. One isolate of the P. triticina race MFT [North American System of Races Nomenclature, Long and Kolmer (1989)] was used based on the results from preliminary trials 
that indicated a differential response between the 2 parents. After inoculation, plants were kept overnight in a high-humidity chamber, and the rust reaction was evaluated 18-20 days later.

Visual classification was made according to the Roelfs "Wheat Leaf Rust Severity Scale", which is based on lesion size (from 1, indicating resistance, to 8, indicating susceptibility) and severity of a modified Cobb scale. Significant deviations from disomic ratios toward monosomic ratios were used to identify chromosomes carrying the resistance genes. The chi-square test was used to evaluate data from segregated populations.

\section{Molecular marker analysis}

\section{Plant material and DNA extraction}

A population of $92 \mathrm{~F}_{7}$ inbred lines and resistant Toropi (female) and susceptible IAC 13 (male) parents were used in this analysis. Toropi is resistant to leaf rust at the adult plant stage but susceptible to all known races of Brazilian leaf rust at the seedling stage. IAC 13 is susceptible to all known races of Brazilian leaf rust at the seedling and adult plant stages (Barcellos et al., 2000). The advancement of the $\mathrm{F}_{2}$ through $\mathrm{F}_{7}$ populations and the leaf rust score for the $\mathrm{F}_{7}$ population were made at the OR Melhoramento de Sementes and the Brazilian Wheat Research Center, respectively. Analyses of the data scored from the $\mathrm{F}_{7}$ population confirmed the presence of 2 recessive genes previously identified in the $\mathrm{F}_{2}$ population by Barcellos et al. (2000). For the molecular analysis, 10 plants from each $\mathrm{F}_{7}$ inbred line and the parents were grown in greenhouse flats until leaf tissue was available for harvesting (after approximately 2 weeks). DNA extraction from each $\mathrm{F}_{7}$ inbred line was performed according to the CTAB protocol published by Murray and Thompson (1980). For AFLP analysis, 2 bulk samples (Michelmore et al., 1991) were generated using a mixture of equal amounts of DNA extracted from 10 of the most susceptible $\mathrm{F}_{7}$ inbred lines (susceptible bulk) and from 10 of the most resistant $\mathrm{F}_{7}$ inbred lines (resistant bulk).

\section{AFLP analysis}

Ninety-three AFLP primer combinations were tested with DNA from the bulk samples and parents (Toropi and IAC 13). Primers with potential polymorphisms associated with leaf rust APR were selected and tested in the $\mathrm{F}_{7}$ inbred line population. AFLP reactions were performed as described by Vos et al. (1995), with minor modifications. Genomic DNA (1 $\mu \mathrm{g})$ was simultaneously digested using 2 restriction endonucleases: $5 \mathrm{U}$ MseI and $5 \mathrm{U}$ Pst $\mathrm{I}$, and the enzyme reactions were then quenched via heat inactivation. Genomic DNA fragments were ligated to PstI adapters (2.5 $\mu \mathrm{M}$ Pa1.1: 5'-GAC TGC GTA GGT GCA-3' and Pa1.2: 5'-CCT ACG CAG TCT ACG AG-3') and MseI adapters (2.5 $\mu \mathrm{M}$ Ma1.1: 5'-GAC GAT GAG TCC TGA G-3' and Ma1.2: 5'-TAC TCA GGA CTC AT-3') using a ligation buffer containing ATP, $1 \mathrm{U}$ T4 DNA ligase, and sterile distilled water up to a final volume of $50 \mu \mathrm{L}$. This reaction was incubated at room temperature for $2 \mathrm{~h}$. Preamplification was performed using primers complementary to the PstI adapter (5'-GAC TGC GTA GGT GCA GA-3') and MseI adapter (5'-GAT GAG TCC TGA GTA AC-3') sequences, ligated to the DNA plus 1 additional selective nucleotide. Selective amplification was performed using preamplified DNA and primers containing three selective nucleotides. 


\section{SSR analysis}

After finding AFLP markers associated with trp-1 and trp-2, we used all SSR and STS markers previously mapped on wheat chromosomes $1 \mathrm{~A}$ and $4 \mathrm{D}$ and available in a public database for the molecular mapping of trp-1 and trp-2. We used only the markers present in these 2 chromosomes because monosomic analysis revealed that trp-1 and trp-2 are on these chromosomes. Thirty-four SSR and 4 STS markers were identified (Table 1) and used to map trp-1 and trp-2. Polymerase chain reaction (PCR) was performed according to the protocols for each primer established by Röder et al. (1998), Pestsova et al. (2000), and Song et al. (2005). The parents were screened using SSR and STS primers. Markers exhibiting polymorphisms between the parents were run in the $\mathrm{F}_{7}$ population. The STS markers (Table 2) were converted from barley restriction fragment length polymorphism (RFLP) markers mapped on wheat chromosome 4D. The RFLP marker sequences were obtained from the National Center for Biotechnology Information database. Primer design and PCR optimization for the new STS markers were performed in our laboratory.

Table 1. Chromosome positions and polymorphisms (between Toropi and IAC 13 cultivars) of simple sequence repeat (SSR) and STS markers used to anchor AFLP markers associated with the adult plant resistance genes trp-1 and trp-2 from the wheat cultivar Toropi.

\begin{tabular}{|c|c|c|c|c|c|c|c|c|}
\hline $\mathrm{SSR}^{\mathrm{a}}$ & Chromosome $^{\mathrm{a}}$ & Polymorphic & $\mathrm{SSR}^{\mathrm{a}}$ & Chromosome $^{\mathrm{a}}$ & Polymorphic & $\mathrm{SSR}^{\mathrm{a}}$ & Chromosome $^{\mathrm{a}}$ & Polymorphic \\
\hline Xgwm33 & $1 \mathrm{AS}$ & yes & Xbarc25 & $1 \mathrm{AS}$ & no & Xbarc308.1 & 4DS & no \\
\hline Xgwm99 & $1 \mathrm{AL}$ & yes & Xbarc28 & $1 \mathrm{AS}$ & no & Xbarc334 & 4DS & yes \\
\hline Xgwm136 & $1 \mathrm{AS}$ & yes & Xbarc48.1 & $4 \mathrm{DL}$ & no & Xbarc1048 & $1 \mathrm{AS}$ & no \\
\hline Xgwm164 & $1 \mathrm{AL}$ & no & Xbarc98 & $4 \mathrm{DL}$ & no & Xbarc1069 & $4 \mathrm{DL}$ & no \\
\hline Xgwm 165 & $4 \mathrm{DL}$ & no & Xbarc105 & 4DS & yes & Xbarc1095 & $1 \mathrm{AS}$ & no \\
\hline Xgwm194 & $4 \mathrm{DL}$ & yes & Xbarc119 & $1 \mathrm{AS}$ & no & Xbarc1118 & 4DS & no \\
\hline Xgwm608 & $4 \mathrm{DL}$ & yes & Xbarc120 & $1 \mathrm{AS}$ & no & Xbarc1145 & $4 \mathrm{D}$ & no \\
\hline Xgwm609 & $4 \mathrm{DL}$ & no & Xbarc148 & $1 \mathrm{AS}$ & yes & Xbarc1148 & $4 \mathrm{DL}$ & no \\
\hline Xgdm34 & $4 \mathrm{D}$ & no & Xbarc162 & $1 \mathrm{AS}$ & no & STS1395 & $4 \mathrm{D}$ & yes \\
\hline Xgdm40 & $4 \mathrm{D}$ & no & Xbarc217 & 4DS & no & STS1117 & $4 \mathrm{D}$ & no \\
\hline Xgdm61 & $4 \mathrm{DL}$ & yes & Xbarc225 & 4DS & no & STS1230 & $4 \mathrm{D}$ & no \\
\hline $\mathrm{Xgdm} 125$ & $4 \mathrm{DL}$ & yes & Xbarc263 & $1 \mathrm{AS}$ & no & STS464 & $4 \mathrm{D}$ & no \\
\hline Xgdm129 & 4DS & yes & Xbarc288 & 4DS & yes & & & \\
\hline
\end{tabular}

${ }^{a}$ According to Röder et al. (1998), Pestsova et al. (2000) and Song et al. (2005).

\section{Separation of AFLP and SSR markers on denaturing polyacrylamide gels and STS on agarose gels}

Products from AFLP selective amplification and SSR amplification were separated on a $6 \%$ denaturing polyacrylamide sequencing gel using standard sequencing electrophoresis protocols. Pre-electrophoresis was performed at constant power $(\sim 85 \mathrm{~W})$ for approximately $45 \mathrm{~min}$. The gel was loaded with $5 \mu \mathrm{L}$ each sample and 1 sample of the pGEM DNA marker, and run for $2 \mathrm{~h}$ and $30 \mathrm{~min}$ at constant power $(2000 \mathrm{~V}$ and $85 \mathrm{~W})$. After the electrophoresis was complete, the gel was stained using a silver staining protocol. STS marker products were run on $2 \%$ agarose gels and stained with ethidium bromide.

\section{Data analysis}

Segregation data for the bulks was visually recorded. AFLP markers potentially asso- 
ciated with leaf rust resistance were further evaluated on the $\mathrm{F}_{7}$ recombinant inbred line (RIL). The segregation of each marker for the expected band ratio was tested in the $\mathrm{F}_{7}$ RIL population using the LINKAGE-1 version 3.27 program (Suiter et al., 1983).

The normality of the phenotypic data for leaf rust resistance was tested, and the data were then transformed using the square root value of $X+10$. Individual single ANOVAs were analyzed with the SAS program by using each marker as an independent variable and the leaf rust resistance data as the dependent variable. Linkage between 2 markers potentially associated with leaf rust resistance was tested with LINKAGE-1. Furthermore, the linkage and distances among the AFLP, SSR, and STS markers and leaf rust resistance genes were estimated using LINKAGE-1.

\section{RESULTS}

\section{Monosomic analysis}

Rust APR evaluation was carried out on 1079 segregant plants from 20 monosomic families from the Toropi/Cappelle-Desprez cross (Table 2). Segregation indicated the presence of 2 recessive genes ( 7 resistant:9 susceptible). The same segregation rate was observed in the $\mathrm{F}_{2}$ population in previous genetic studies of APR from crosses between the Toropi cultivar and the susceptible IAC 13 cultivar (Barcellos et al., 2000). Distorted segregation ratios were observed in the monosomic families of chromosomes 1A and 4D, indicating that the APR genes in the Toropi cultivar are located on these chromosomes (Table 2). The results confirmed the 2-gene hypothesis. The absence of the 1B progeny, which was unavailable for testing, did not have any influence on the interpretation of results.

\begin{tabular}{|c|c|c|c|c|c|c|}
\hline \multirow[t]{2}{*}{ Monosomic } & \multicolumn{2}{|c|}{ Resistant plants } & \multicolumn{2}{|c|}{ Susceptible plants } & \multicolumn{2}{|c|}{$\chi^{2}$} \\
\hline & Number & $\%$ & Number & $\%$ & 2 recessive genes & Probability \\
\hline $1 \mathrm{~A}$ & 21 & 26.9 & 57 & 73.1 & 8.30 & $0.001-0.01$ \\
\hline $2 \mathrm{~A}$ & 24 & 51.1 & 23 & 48.9 & 0.75 & $0.30-0.50$ \\
\hline $3 \mathrm{~A}$ & 16 & 34.0 & 31 & 65.0 & 1.42 & $0.20-0.30$ \\
\hline $4 \mathrm{~A}$ & 26 & 51.0 & 25 & 49.0 & 0.81 & $0.30-0.50$ \\
\hline $5 \mathrm{~A}$ & 23 & 36.5 & 40 & 63.5 & 1.07 & 0.30 \\
\hline $6 \mathrm{~A}$ & 26 & 51.0 & 25 & 49.0 & 0.81 & $0.30-0.50$ \\
\hline $7 \mathrm{~A}$ & 24 & 33.8 & 47 & 66.2 & 2.47 & $0.10-.020$ \\
\hline $1 \mathrm{~B}^{*}$ & - & - & - & - & - & - \\
\hline $2 \mathrm{~B}$ & 24 & 43.6 & 31 & 56.4 & 0.01 & $0.90-0.95$ \\
\hline $3 \mathrm{~B}$ & 23 & 51.1 & 22 & 48.9 & 0.71 & $0.30-0.50$ \\
\hline $4 \mathrm{~B}$ & 25 & 49.0 & 26 & 51.0 & 0.38 & $0.50-0.70$ \\
\hline 5 BL-7BL & 24 & 46.2 & 28 & 53.9 & 0.04 & $0.70-0.90$ \\
\hline 5 BS-7BS & 27 & 42.9 & 36 & 57.1 & 0.0002 & $>0.95$ \\
\hline $6 \mathrm{~B}$ & 21 & 52.5 & 19 & 47.5 & 0.91 & $0.30-0.50$ \\
\hline $1 \mathrm{D}$ & 15 & 39.5 & 23 & 60.5 & 0.14 & $0.70-0.90$ \\
\hline $2 \mathrm{D}$ & 17 & 42.5 & 23 & 57.5 & 0.00 & $>0.95$ \\
\hline $3 \mathrm{D}$ & 12 & 63.6 & 21 & 36.4 & 0.46 & 0.50 \\
\hline $4 \mathrm{D}$ & 15 & 23.8 & 48 & 76.2 & 9.38 & $0.001-0.01$ \\
\hline $5 \mathrm{D}$ & 26 & 47.3 & 29 & 52.7 & 0.16 & $0.50-0.70$ \\
\hline $6 \mathrm{D}$ & 19 & 51.4 & 18 & 48.6 & 0.59 & $0.30-0.50$ \\
\hline $7 \mathrm{D}$ & 19 & 43.2 & 25 & 56.8 & 0.006 & $0.90-0.95$ \\
\hline Cappelle-Desprez/Toropi - Euploid & 22 & 40.0 & 33 & 60.0 & 0.18 & $0.50-0.70$ \\
\hline
\end{tabular}

\footnotetext{
*Not tested. Data in bold show the distorted segregation ratios observed in the monosomic families of chromosomes
} $1 \mathrm{~A}$ and $4 \mathrm{D}$. 


\section{Screening AFLP markers linked to trp-1 and trp-2}

Of the 93 AFLP primer combinations tested, 4 were found to have at least 1 marker potentially associated with adult plant leaf rust resistance. These primer combinations were Paac/Mcgg, Pacg/Mcta, Pacg/Mcac, and Patc/Mcat, and they were further tested on the $\mathrm{F}_{7}$ RIL and parents. A variable number of segregating bands was observed for each of these primer combinations and 20 loci in all were evaluated and tested on the $\mathrm{F}_{7}$ RIL (Table 3). All marker loci were segregated as expected, in that there was the presence and absence of a band in the $\mathrm{F}_{7} \mathrm{RIL}$, indicating the absence of distorted ratios influencing the associations between the markers and segregation data for rust resistance.

Table 3. Square root, F-test, and significance level of ANOVAs performed for the polymorphic AFLP marker loci evaluated on the $\mathrm{F}_{7}$ inbred line population from a Toropi/IAC 13 cross segregation for adult plant resistance to leaf rust.

\begin{tabular}{lccc}
\hline Marker loci & $\mathrm{R}^{2}$ & F-test & Probability \\
\hline XPaac/Mcgg2 & 0.010 & 0.85 & 0.3588 \\
XPaac/Mcgg3 & 0.000 & 0.00 & 0.9606 \\
XPaac/Mcgg4 & 0.015 & 1.18 & 0.2802 \\
XPaac/Mcgg5 & 0.014 & 1.16 & 0.2848 \\
XPaac/Mcgg9 & 0.007 & 0.61 & 0.4368 \\
XPaac/Mcgg11 & 0.007 & 0.60 & 0.4399 \\
XPaac/Mcgg13 & 0.023 & 1.88 & 0.1737 \\
XPaac/Mcgg17 & 0.000 & 0.02 & 0.8918 \\
XPacg/Mcta6.1 & 0.019 & 1.53 & 0.2191 \\
XPacg/Mcta10 & 0.000 & 0.01 & 0.9343 \\
XPacg/Mcta13 & 0.009 & 0.74 & 0.3938 \\
XPacg/Mcta14 & 0.002 & 0.20 & 0.6592 \\
XPacg/Mcta16 & 0.026 & 2.09 & 0.1521 \\
XPacg/Mcac1 & 0.000 & 0.02 & 0.8966 \\
XPacg/Mcac3 & $\mathbf{0 . 0 3 3}$ & $\mathbf{2 . 7 8}$ & $\mathbf{0 . 0 9 9 3}$ \\
XPacg/Mcac4 & 0.012 & 1.02 & 0.3162 \\
XPacg/Mcac6 & $\mathbf{0 . 0 4 9}$ & $\mathbf{4 . 3 1}$ & $\mathbf{0 . 0 4 1 1}$ \\
XPatc/Mcat2 & 0.015 & 1.18 & 0.2814 \\
XPatc/Mcat2.1 & 0.001 & 0.08 & 0.7725 \\
XPatc/Mcat4 & 0.008 & 0.66 & 0.4195 \\
\hline
\end{tabular}

Data in bold show the markers statistically significant different on segregation.

The presence or absence of a band was used to classify phenotypic data for adult plant leaf rust resistance, and an individual ANOVA was performed for each marker. Statistically significant differences between the classes were observed for the markers XPacg/Mcac3 and XPacg/Mcac6 (Table 3). Individually, each marker explained only 3-5\% of the total phenotypic variation (Table 3). However, when both markers were used in a multiple linear regression model, they explained $71.5 \%$ of the variation in the phenotypic data. This result was expected because the leaf rust resistance data for the $\mathrm{F}_{7}$ RIL segregated as 2 recessive genes with additive effects. Linkage between the 2 markers was further tested using LINKAGE-1 program, and the data confirmed that the markers were independent with a recombination of $47 \%, \chi^{2}(0.499)$.

\section{Molecular mapping of trp-1 and trp-2}

We used the data generated from the analyses of the XPacg/Mcac3 and XPacg/Mcac6 
AFLP markers in addition to the phenotypic data in order to map trp-1 and trp-2 on the wheat chromosomes 1A and 4D. Once an SSR marker on chromosomes 1A and/or 4D associated with 1 of these AFLP markers is mapped, it would prove the presence of trp- 1 and trp-2 on these chromosomes. From the SSR markers mapped to chromosome 1A, the marker Xgwm33 was shown to be associated with the AFLP marker XPacg/Mcac3 (38 cM), and SSR Xgwm136 was shown to be associated with trp-1 $(26.5 \mathrm{cM})$, confirming the presence of trp- 1 on the short arm of chromosome 1A (Figure 1). From the SSR markers mapped to chromosome 4D, the SSR marker Xgdm129 was shown to be associated with the AFLP marker XPacg/Mcac6 (26.5 $\mathrm{cM}$ ). With these data, it was possible to map trp-2 to the short arm of chromosome 4D (Figure 1). These results confirmed those of the monosomic stock analyses.

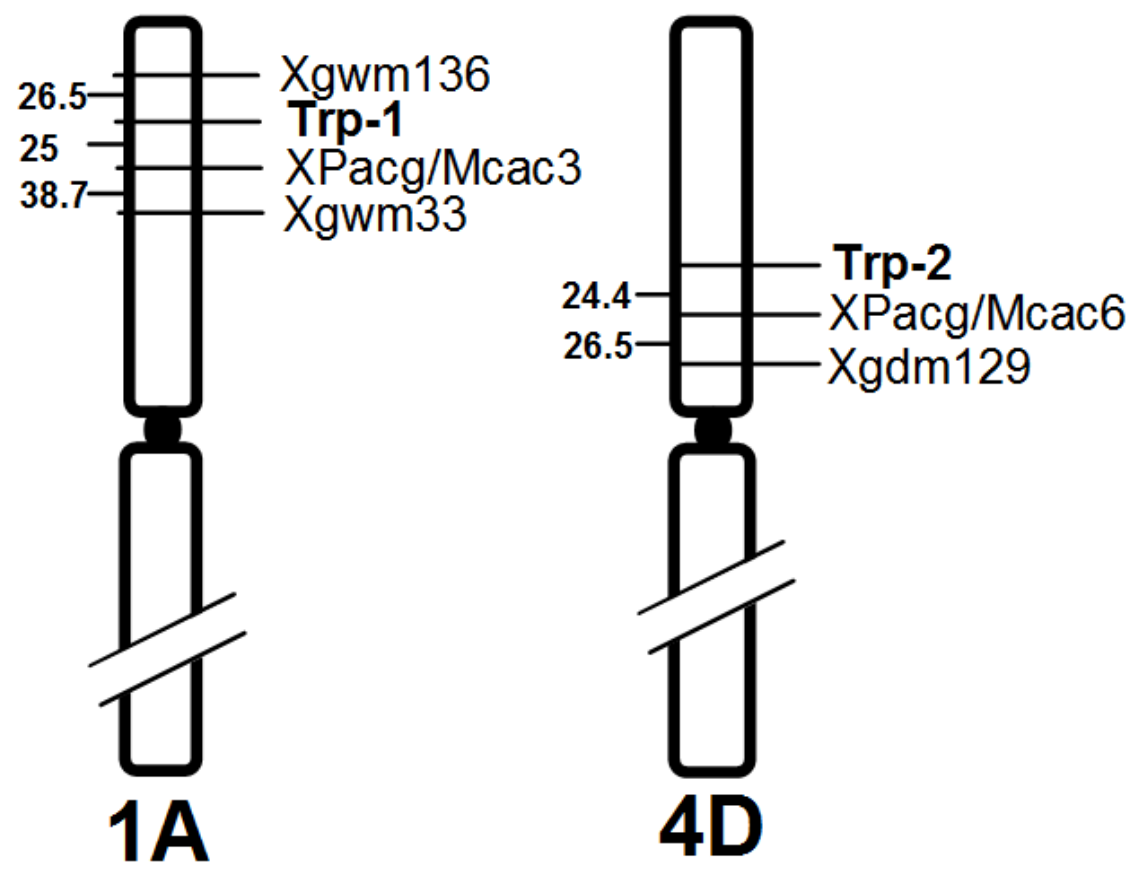

Figure 1. Partial molecular map of the short arm of wheat chromosomes $1 \mathrm{~A}$ and $4 \mathrm{D}$ and the respective location of trp-1 and trp-2. The distances in centimorgans (cM) between markers and genes are shown to the left of the illustrations.

\section{DISCUSSION}

Genetic studies of cereals have shown that slow rusting is often an important component of durable rust resistance (Roelfs, 1988; Lagudah, 2011). However, this resistance type is conferred by more than 1 gene with additive effects, rendering the development of superior genotypes with durable rust resistance through conventional breeding difficult and time consuming. Therefore, mapping and developing molecular markers linked to these genes can aid breeders in the selection of superior genotypes with durable rust resistance.

Many groups have used the AFLP technique to tag loci associated to disease resis- 
tance in wheat. Goodwin et al. (1998) detected an AFLP marker linked to a gene for resistance to Septoria tritici blotch. Hartl et al. (1998) identified AFLP markers for a powdery mildew resistance gene. Guo et al. (2003) identified AFLP markers linked to 1 major QTL controlling Fusarium head blight resistance. Dieguez et al. (2006) tagged the leaf rust resistance gene Lr3 by AFLP. All these examples are major genes or QTLs. Few studies have demonstrated slowrusting gene tagging in wheat via AFLP. Obert et al. (2005) tagged new slow-rusting resistance genes to leaf rust from Afghanistan landraces of wheat using AFLP, and mapped this new gene on chromosome 5BS with SSRs. Rosewarne et al. (2006) identified and mapped new AFLP markers associated with the Lr46/Yr29 complex, an important gene to APR in wheat. In oat, which has the largest cereal genome, Barbosa et al. (2006) tagged partial resistance to oat crown rust by using the AFLP technique. In our present study, we have tagged 2 new APR genes to leaf rust in wheat by using AFLP. These genes were mapped in a wheat chromosome region that has few markers. Our present results and those of previous studies by other groups reinforce the notion that the AFLP technique is a powerful tool for tagging genes in large genomes, mainly when previous knowledge of gene location and saturated SSR maps are not available.

Howes (1986) mapped the Lrl0 gene on chromosome 1AS, the same chromosome arm where we mapped trp-1. We wanted to determine if these genes were the same. According to phenotypic analyses, $\operatorname{trp}-1$ exhibits a different resistance reaction from $L r 10$, which is a dominant gene conferring resistance in the seedling stage, whereas $t r p-1$ is a recessive gene and confers APR (Barcellos et al., 2000). Therefore, we can affirm that trp-1 is not Lr10.

We mapped trp-2 on chromosome 4DS of wheat Toropi cultivar. No previous reports in the literature of leaf rust genes on chromosome 4DS in other wheat cultivar have been published. Herrera-Foessel et al. (2011) mapped the new slow-rusting resistance gene Lr67 on the long arm of chromosome 4D (4DL). Two markers (Xgwm165 and Xbarc98) that were previously associated with $\operatorname{Lr67}$ (Herrera-Foessel et al., 2011) were also used in our present study, and no polymorphism was observed between Toropi/IAC 13. All markers found to be associated with $\operatorname{Lr} 47$ were below the centromere, and those associated with $\operatorname{trp}$ - 1 were all above the centromere (Figure 1; Herrera-Foessel et al., 2011); therefore, we can state that trp-1 and Lr47 are not the same. Raupp et al. (2001) used monosomic analysis for Lr39 interchromosomal mapping and SSR markers for intrachromosomal mapping. Monosomic and ditelosomic analysis indicated that $\operatorname{Lr} 39$ is independent of the centromere on the short arm of chromosome 2D. Eight microsatellite markers for 2DS were used for linkage analysis, which confirmed the location of the gene on 2DS. The mapping of Lr39 near the telomere of 2DS distinguishes it from the $L r 2$ and $L r 22$ loci. The same strategy was used in our study, and the results show that trp-1 is on the short arm of chromosome 1A and that it differs from $\operatorname{Lr} 10$, whereas trp-2 is on the short arm of chromosome 4D and is different from $\operatorname{Lr} 47$.

Mapping of trp-2 and $L r 47$ to chromosome 4DS could lead to the development of a new strategy for locating genes on this chromosome. According to Keller and Feuillet (2000), wheat genes are organized in "gene islands". In other words, the genes are organized into isolated groups that are separated by great amounts of repetitive DNA. Using derived probes of resistance genes, Li et al. (1999) mapped 167 loci in all wheat chromosomes except for chromosome 4D. These authors also observed that these genes are enclosed in specific chromosome areas. Mapping 1 gene in a chromosome tends to facilitate the search for new genes located in the same chromosome.

The physiological mechanisms responsible for durable resistance have been exten- 
sively discussed. Alvarez-Zamorano (1995) studied resistance mechanisms conferred by Lr34 using electronic microscopy and observed that this gene displayed a resistance mechanism different from known hypersensitive response mechanisms. When infected with fungi, plants containing Lr34 accumulate unknown electrodense substances in the cells near sites where haustorial mother cells are established for the formation of haustoria. It appears that this accumulation (cell wall apposition) causes thickening of the cell wall, which reduces the establishment of the fungal haustorial tube. If haustoria are formed, the slow mycelial growth may be due to restricted movement of the fungus from one cell to another by a similar phenomenon (Alvarez-Zamorano, 1995). This resistance mechanism is similar to that conferred by the mlo gene in barley, which also confers durable resistance, in this case, against barley powdery mildew. The mlo gene exhibits a completely different structure from resistance genes that have already been cloned (it does not contain NBS-LRR domains). By using derived probes for resistance genes, Li et al. (1999) mapped 167 loci in all wheat chromosome regions containing previously mapped resistance genes, except for $\operatorname{Lr} 34$ regions and the entire $4 \mathrm{D}$ chromosome. These authors suggest that $\operatorname{Lr} 34$ is different from NBS-LRR resistance genes. Recently, refined analysis of $L r 34$ loci shows that this gene encodes a putative ABC transporter (Krattinger et al., 2009). These data confirm that $L r 34$ is a resistance gene different from NBS-LRR resistance genes, which Li et al. (1999) proposed. In our present study, trp-2 was mapped to chromosome 4DS (no NBS-LRR areas were present in this chromosome) and exhibited a resistance type similar to Lr34 and mlo. We suggest that trp-2 is also different from NBS-LRR resistance genes. This finding will be confirmed after we clone trp-2.

In this study, we mapped the 2 leaf rust APR genes trp- 1 and trp-2 in the Brazilian wheat cultivar Toropi. The trp-2 gene is the first leaf rust gene mapped on the wheat chromosome 4DS. Identifying molecular markers linked to trp-1 and trp-2 and the mapping of these genes are the first steps toward the development of a marker-assisted selection system for APR genes that are associated with leaf rust in wheat. Future studies aimed at identifying other markers in these regions and subsequently converting them into PCR-specific markers will contribute toward their use in marker-assisted selection for APR in wheat.

\section{ACKNOWLEDGMENTS} nológico $(\mathrm{CNPq})$.

\section{REFERENCES}

Alvarez-Zamorano R (1995). Patogenesis de Puccinia recondita Rob. Ex Desm. f. sp. tritici y la Resistencia en Trigo. PhD thesis, Colégio Postgraduados, Montecillos.

Anikster Y, Bushnell WR, Eilam T, Manisterski J, et al. (1997). Puccinia recondita causing leaf rust on cultivated wheats, wild wheats, and rye. Can. J. Bot. 75: 2082-2096.

Bai DP, Knott DR and Zale J (1998). The transfer of leaf rust resistance from Triticum timopheevii to durum and bread wheat and the location of one gene are chromosome 1A. Can. J. Plant Sci. 78: 683-687.

Barbosa MM, Federizzi LC, Milach SCK, Martinelli JA, et al. (2006). Molecular mapping and identification of QTL's associated to oat crown rust partial resistance. Euphytica 150: 257-269.

Barcellos AL, Roelfs AP and Moraes-Fernandes MIB (2000). Inheritance of adult plant leaf rust resistance in the Brazilian wheat cultivar Toropi. Plant Dis. 84: 90-93.

Bariana HS and McIntosh RA (1993). Cytogenetic studies in wheat. XV. Location of rust resistance genes in VPM1 and 
their genetic linkage with other disease resistance genes in chromosome 2A. Genome 36: 476-482.

Bjarko ME and Line RF (1988). Quantitative determination of the gene action of leaf rust resistance in four cultivars of wheat, Triticum aestivum. Phytopathology 78: 451-456.

Chen CX, Wang ZL, Yang DE, Ye CJ, et al. (2004). Molecular tagging and genetic mapping of the disease resistance gene $R p p Q$ to southern corn rust. Theor. Appl. Genet. 108: 945-950.

De Giovanni C, Dell'Orco P, Bruno A, Ciccarese F, et al. (2004). Identification of PCR-based markers (RAPD, AFLP) linked to a novel powdery mildew resistance gene (ol-2) in tomato. Plant Sci. 166: 41-48.

Dieguez MJ, Altieri E, Ingala LR, Perera E, et al. (2006). Physical and genetic mapping of amplified fragment length polymorphisms and the leaf rust resistance $L r 3$ gene on chromosome 6BL of wheat. Theor. Appl. Genet. 112: 251-257.

Dubcovsky J, Lukaszewski AJ, Echaine M, Antonelli EF, et al. (1998). Molecular characterization of two Triticum speltoides interstitial translocations carryng leaf rust and greenbug resistance genes. Crop Sci. 38: 1655-1660.

Dussle CM, Quint M, Melchinger AE, Xu ML, et al. (2003). Saturation of two chromosome regions conferring resistance to SCMV with SSR and AFLP markers by targeted BSA. Theor. Appl. Genet. 106: 485-493.

Goodwin SB, Hu X and Shaner G (1998). An AFLP Marker Linked to a Gene for Resistance to Septoria tritici Blotch in Wheat. Proceedings of the 9th International Wheat Genetics Symposium Saskatoon, Saskatchewan, 108-110.

Guo PG, Bai GH and Shaner GE (2003). AFLP and STS tagging of a major QTL for Fusarium head blight resistance in wheat. Theor. Appl. Genet. 106: 1011-1017.

Hartl L, Mori S and Schweizer G (1998). Identification of a Diagnostic Molecular Marker for the Powdery Mildew Resistance Gene Pm $4 b$ Based on Fluorescently Labelled AFLPs. Proceedings of the 9th International Wheat Genetics Symposium Saskatoon, Saskatchewan, 111-113.

Herrera-Foessel SA, Lagudah ES, Huerta-Espino J, Hayden MJ, et al. (2011). New slow-rusting leaf rust and stripe rust resistance genes $\operatorname{Lr67}$ and Yr46 in wheat are pleiotropic or closely linked. Theor. Appl. Genet. 122: 239-249.

Herrera-Foessel SA, Singh RP, Huerta-Espino J, Rosewarne GM, et al. (2012). Lr68: a new gene conferring slow rusting resistance to leaf rust in wheat. Theor. Appl. Genet. 124: 1475-1486.

Howes NK (1986). Linkage between the $L r 10$ gene conditioning resistance to leaf rust, two endosperm proteins and hairy glumes in hexaploid wheat. Can. J. Genet. Cytol. 28: 595-600.

Huerta-Espino J, Singh RP, German S, McCallum SBD, et al. (2011). Global status of wheat leaf rust caused by Puccinia triticina. Euphytica 179: 143-160.

Keller B and Feuillet C (2000). Colinearity and gene density in grass genomes. Trends Plant Sci. 5: 246-251.

Krattinger SG, Lagudah ES, Spielmeyer WSP, Huerta-Espino J, et al. (2009). A putative ABC transporter confers durable resistance to multiple fungal pathogens in wheat. Science 323: 1360-1363.

Lagudah ES (2011). Molecular genetics of race non-specific rust resistance in wheat. Euphytica 179: 81-91.

Li WL, Faris JD, Chittoor JM, Leach JE, et al. (1999). Genomic mapping of defense response genes in wheat. Theor. Appl. Genet. 98: 226-233.

Lin JJ and Kuo J (1995). AFLPTM, a novel PCR-based assay for plant and bacterial DNA fingerprinting. Focus 17: 66-70.

Long DL and Kolmer JA (1989). A North American system of nomenclature for Puccinia recondita f. sp. tritici. Phytopathology 79: 525-529.

McIntosh RA, Friebe B, Jiang JTD, The D, et al. (1995). Cytogenetical studies in wheat. XVI. Chromosomal location of a new gene for resistance to leaf rust in a Japanese wheat-rye translocation line. Euphytica 82: 141-147.

Michelmore RW, Paran I and Kesseli RV (1991). Identification of markers linked to disease-resistance genes by bulked segregant analysis: a rapid method to detect markers in specific genomic regions by using segregating populations. Proc. Natl. Acad. Sci. U. S. A. 88: 9828-9832.

Murray MG and Thompson WF (1980). Rapid isolation of high molecular weight plant DNA. Nucleic Acids Res. 8: 43214325.

Obert DE, Fritz AK, Moran JL, Singh S, et al. (2005). Identification and molecular tagging of a gene from PI 289824 conferring resistance to leaf rust (Puccinia triticina) in wheat. Theor. Appl. Genet. 110: 1439-1444.

Pestsova E, Ganal MW and Roder MS (2000). Isolation and mapping of microsatellite markers specific for the D genome of bread wheat. Genome 43: 689-697.

Raupp WJ, Sukhwinder S, Brown-Guedira GL and Gill BS (2001). Cytogenetic and molecular mapping of the leaf rust resistance gene Lr39 in wheat. Theor. Appl. Genet. 102: 347-352.

Roelfs AP (1988). Resistance to Leaf Rust and Stem Rust in Wheat. In: Breeding Strategies for Resistance to the Rusts of Wheat (Simmonds NW and Rajaram S, eds.). CIMMYT, Mexico, 10-22.

Rosewarne GM, Singh RP, Huerta-Espino J, William HM, et al. (2006). Leaf tip necrosis, molecular markers and $\beta 1$ proteasome subunits associated with the slow rusting resistance genes Lr46/Yr29. Theor. Appl. Genet. 112: 500-508.

Röder MS, Korzun V, Wendehake K, Plaschke J, et al. (1998). A microsatellite map of wheat. Genetics 149: 2007-2023.

Sears ER (1939). Cytogenetic studies with polyploid species of wheat. I. Chromosomal aberrations in the progeny of a 
haploid of Triticum vulgare. Genetics 24: 509-523.

Singh RP and Rajaram S (1992). Genetics of adult-plant resistance to leaf rust in Frontana and three CIMMYT wheats. Genome 5: 24-31.

Singh RP, Huerta-Espino J and William HM (2005). Genetics and breeding for durable resistance to leaf and stripe rusts in wheat. Turk. J. Agric. For. 29: 121-127.

Singh RP, Huerta-Espino J, Bhavani S, Herrera-Foessel AS, et al. (2011). Race non-specific resistance to rust diseases in CIMMYT spring wheats. Euphytica 179: 175-186.

Song QJ, Shi JR, Singh S, Fickus EW, et al. (2005). Development and mapping of microsatellite (SSR) markers in wheat. Theor. Appl. Genet. 110: 550-560.

Suiter KA, Wendel JF and Case JS (1983). LINKAGE-1: a PASCAL computer program for the detection and analysis of genetic linkage. J. Hered. 74: 203-204.

Vos P, Hogers R, Bleeker M, Reijans M, et al. (1995). AFLP: a new technique for DNA fingerprinting. Nucleic Acids Res. 23: 4407-4414

Weng Y and Lazar MD (2002). Amplified fragment length polymorphism and simple sequence repeat-based molecular tagging and mapping of greenbug resistance gene Gb3 in wheat. Plant Breed. 121: 218-223.

William HM, Singh RP, Huerta-Espino J, Palacios G, et al. (2006). Characterization of genetic loci conferring adult plant resistance to leaf rust and stripe rust in spring wheat. Genome 49: 977-990. 